\title{
The Implementation of Environmental Education to Achieve Sustainable Development: Literature Review
}

\author{
Gayatri Hanna Permanasari ${ }^{1 *}$, Suherman Suherman ${ }^{2}$, and Lilin Budiati ${ }^{3}$ \\ ${ }^{1}$ Master Program of Environmental Science, School of Postgraduate Studies, Diponegoro University, \\ Semarang - Indonesia \\ ${ }^{2}$ Department of Chemical Engineering, Faculty of Engineering, Diponegoro University, Semarang - \\ Indonesia \\ ${ }^{3}$ Urban Planning Department of Vocational School, Diponegoro University, Semarang - Indonesia
}

\begin{abstract}
Environmental issues arise in different regions due to human activities using the natural resources without considering the sustainability for future generations. Education has an important role in the sustainable development because it is related to other sustainable development goals. The purpose of this study is to analyze the implementation of environmental education through Education for Sustainable Development (ESD) approach. A literature review of previous research studies used to identify the relationship between environmental education and ESD. The result of this study is a framework for conducting more comprehensive research to overcome regional environmental problems through formal education. It showed that environmental education has the same approach as ESD, which is interdisciplinary, lifelong learning, and prioritizes local cultures in observation and solving local to international issues. Both environmental education and ESD aim to change people's perspectives and behaviour.
\end{abstract}

\section{Introduction}

The increase in population, the necessities of life, and the advancement of science and technology have resulted in several ecological crises [1]. In order to improve the ethics of modern society in dealing with nature and fellow humans, numerous cases of contamination and environmental degradation that arise in various regions must be addressed by shifts in the perspective of ecological and systematic research. This is expressed in a global collaborative movement involving all communities in order for environmental ethics to become a culture that is maintained, taught, and passed on to other people and future generations [2]. One way to teach environmental ethics is through educational networks, which can help to shape individual attitudes and actions in coping with environmental issues [3].

The Education for Sustainable Development (ESD) approach is implemented because education plays a vital role in sustainable development by producing a generation that is

* Corresponding author: gayatri.hanna@gmail.com 
literate, numerate, analytical, problem-solving, and decision-making skills and attitudes to face local and global challenges [4]. Quality education (Goal 4) is linked to other goals in the concept of sustainable development, as shown in Table 1. This paper aims to investigate how environmental education can be used to achieve sustainable development using an ESD approach and a literature review.

Table 1. The Relationship of Quality Education (Goal 4) to Other Sustainable Development Goals.

\begin{tabular}{|c|l|}
\hline Goal & \multicolumn{1}{c|}{ The Relationship to Goal 4 } \\
\hline Goal 6 & $\begin{array}{l}\text { Education can improve skills and abilities in using natural resources more } \\
\text { sustainably as well as improving sanitation }\end{array}$ \\
\hline Goal 7 & $\begin{array}{l}\text { Energy conservation efforts and the availability of renewable energy sources can be } \\
\text { encouraged through education }\end{array}$ \\
\hline Goal 11 & $\begin{array}{l}\text { Education can increase community involvement in creating sustainable and disaster- } \\
\text { resilient cities }\end{array}$ \\
\hline Goal 12 & $\begin{array}{l}\text { Education has the potential to alter production patterns as well as consumer } \\
\text { perceptions of sustainably produced goods, thereby reducing waste production }\end{array}$ \\
\hline Goal 13 & $\begin{array}{l}\text { Education is a tool for increasing public awareness of the effects of climate change, } \\
\text { as well as adaptation and mitigation efforts, particularly at the local level }\end{array}$ \\
\hline Goal 15 & $\begin{array}{l}\text { Education is an effort to improve skills and capacities to support sustainable } \\
\text { livelihoods as well as the preservation of natural resources and biodiversity }\end{array}$ \\
\hline
\end{tabular}

\section{Literature review}

\subsection{Environmental education at schools}

The Ministry of Environment and Forestry defines environmental education as an effort to increase knowledge, skills, attitudes, and acts of concern for individuals, communities, organizations, and various parts of society through the Regulation of the Minister of Environment and Forestry Number P.52 / MENLHK / SETJEN / KUM.1 / 9/2019 regarding the Caring and Cultured Movement for the Environment at Schools.

The implication of environmental education aims to raise awareness, develop caring and responsible behavior, and produce good students in environmental management [5]. Practically, environmental education is a lifelong learning process with an interdisciplinary approach that examines environmental issues from local to international levels, including the importance of local to international cooperation to prevent and overcome environmental problems and consider environmental components in development plans [1].

Environmental education is a powerful tool for instilling knowledge, skills, and a caring attitude toward the environment. Students are exposed to actual environmental events and conditions, learning that incorporates the environment becomes more real and factual [6;7]. Schools that have implemented environmental education can produce communities that can solve environmental problems and serve as role models for preserving environmental functions [8].

Schools that have implemented environmental education have implemented simply sustainable development because they use energy and resources efficiently by focusing on the performance and comfort of their students. Schools that have successfully implemented environmental education have several characteristics, including conserving water and energy and lowering the amount of waste entering the landfill [9]. Schools are supposed to minimize 
behaviors that contribute to climate change, environmental degradation, and the use of unnecessary resources through environmental education, as shown by improvements in societal attitudes and behavior [10].

\subsection{Education for Sustainable Development (ESD) approach}

Education is an investment made for the next generation to improve the economic well-being of families and communities so that the educational path is regarded as the foundation for economic development and industrial development [11]. In Indonesia, education programs are implemented by Law Number 20 of 2003 regarding the National Education System mentions that the diversity of regional and environmental potentials has to be integrated into the curriculum according to the level of education. This program is in line with the ESD approach, which is based on local interests and cultures and covers topics such as biodiversity, climate change education, disaster risk reduction, poverty reduction, health improvement, sustainable lifestyles, and water conservation. In its implementation, ESD must meet the following seven criteria [12]:

a. Student-centred education, where the teacher serves as a facilitator, allows students to be active and responsible participants in their learning process.

b. Education is carried out interdisciplinary and holistically, so ESD is present in various curricula and is not limited to one subject.

c. Education employs a variety of pedagogical methods to achieve a learning goal.

d. Education is based on patterns of systems thinking to encourage students to understand complexity, seek connections, and find solutions to problems that threaten sustainability.

e. Education raises values in order to increase participation and responsibility in decision-making, as well as to improve critical thinking and problem-solving abilities.

f. Education prioritizes local cultural approaches, local and global issues.

g. Lifelong learning without knowing the boundaries of gender, age, and learning resources.

The ESD approach is a strategic tool used at all levels of education with a community diversity approach [13]. The ESD approach improves students' various characteristics, such as collaboration, communication, environmental care, and independence, while increasing critical thinking skills and creativity can be accomplished by habituating outside learning activities [14].

\section{Research Methodology}

This study employed the literature review method, with the literature published between 2010 and 2021, including books, journals, and research findings on environmental education and ESD. The results of this literature review were then used to develop various aspects to be investigated in a study on the application of environmental education using the ESD approach.

\section{Result and discussion}

The results of the synthesis are presented in Table 2 and are based on the literature studies related to the efforts to achieve sustainable development through the implementation of environmental education at schools. 
Table 2. The Result of the Literature Synthesis used in the Research.

\begin{tabular}{|c|c|c|}
\hline No. & Writer (Year) & Reviewed Topic Descriptions \\
\hline \multicolumn{3}{|c|}{ Substance: Environmental problems } \\
\hline 1. & Keraf (2010) & $\begin{array}{l}\text { - The ecological crisis must be overcome by changing the ecological and } \\
\text { comprehensive perspective in science in order to change the ethics of } \\
\text { modern society in interacting with nature and fellow humans. } \\
\text { - Ethics manifests itself in a collaborative movement involving all } \\
\text { communities in order for environmental ethics becoming a culture }\end{array}$ \\
\hline 2. & $\begin{array}{l}\text { Hudha and } \\
\text { Rahardjanto } \\
\text { (2018) }\end{array}$ & $\begin{array}{l}\text { Environmental ethics can be taught through educational channels to } \\
\text { shape individual attitudes that manifest in behavior when dealing with } \\
\text { environmental problems. }\end{array}$ \\
\hline \multicolumn{3}{|c|}{ Substance: Sustainable development } \\
\hline 3. & $\begin{array}{l}\text { UNESCO } \\
(2018)\end{array}$ & $\begin{array}{l}\text { - The critical role of education in achieving sustainable development: } \\
\text { producing a generation capable of literacy, counting, analyzing, and } \\
\text { solving problems, as well as having the skills and attitudes to face local } \\
\text { and global challenges. } \\
\text { - Goal } 4 \text { is associated with Goals } 6,7,11,12,13 \text {, and } 15 \text {. }\end{array}$ \\
\hline \multicolumn{3}{|c|}{ Substance: Environmental education } \\
\hline 4. & $\begin{array}{l}\text { Daryanto and } \\
\text { Suprihatin } \\
(2013)\end{array}$ & $\begin{array}{l}\text { Practice of environmental education: } \\
\text { 1. Lifelong learning } \\
\text { 2. Interdisciplinary in nature } \\
\text { 3. Evaluating environmental issues at the local, regional, and } \\
\text { international levels } \\
\text { 4. Evaluating local, regional, and international collaboration to prevent } \\
\text { and solve environmental problems } \\
\text { 5. Considering the environmental aspect of the development strategy }\end{array}$ \\
\hline 5. & $\begin{array}{l}\text { Zhao et al. } \\
\text { (2015) }\end{array}$ & $\begin{array}{l}\text { - Green School : educational facilities that have implemented } \\
\text { environmental education (environmental aspects) so that they have an } \\
\text { efficient use of energy and resources (economic aspects) and improve } \\
\text { the performance and comfort of school residents (social aspects). } \\
\text { - Characteristics of Green School: } \\
\text { 1.Energy conservation } \\
\text { 2. Water conservation } \\
\text { Reducing the burden of waste piled up in the landfills }\end{array}$ \\
\hline 6. & $\begin{array}{l}\text { Okasha et al. } \\
(2016)\end{array}$ & $\begin{array}{l}\text { The implementation of environmental education can result in a } \\
\text { community that is capable of solving environmental problems and } \\
\text { serving as a model of responsible behavior for environmental } \\
\text { sustainability. }\end{array}$ \\
\hline 7. & $\begin{array}{l}\text { Iwan dan Rao } \\
\text { (2017) }\end{array}$ & $\begin{array}{l}\text { Schools that incorporate environmental education as part of the } \\
\text { implementation of education for sustainable development have more } \\
\text { creative teacher because they must be able to compile a curriculum that } \\
\text { is in accordance with local conditions and turn schools into learning } \\
\text { resources. }\end{array}$ \\
\hline 8. & $\begin{array}{l}\text { Tucker dan } \\
\text { Izadpanahi } \\
\text { (2017). }\end{array}$ & $\begin{array}{l}\text { Environmental education is essential for achieving sustainable } \\
\text { development and changing community behavior. }\end{array}$ \\
\hline 9. & $\begin{array}{l}\text { Fua et al. } \\
\text { (2018). }\end{array}$ & $\begin{array}{l}\text { Environmental education is a powerful tool for instilling knowledge, } \\
\text { skills, and a caring attitude toward the environment. }\end{array}$ \\
\hline 10. & $\begin{array}{l}\text { Rahmawati et } \\
\text { al. (2020) }\end{array}$ & $\begin{array}{l}\text { The goal of implementing environmental education: to raise awareness, } \\
\text { foster caring and responsible behavior, and produce students who can } \\
\text { serve as role models for environmental management. }\end{array}$ \\
\hline
\end{tabular}




\begin{tabular}{|c|c|c|}
\hline No. & Writer (Year) & Reviewed Topic Descriptions \\
\hline 11. & $\begin{array}{l}\text { Pebriantika et } \\
\text { al. }(2020)\end{array}$ & $\begin{array}{l}\text { Environmental education schools are expected to reduce activities that } \\
\text { have the potential to impact climate change, environmental degradation, } \\
\text { and excessive energy use by changing people's attitudes and behavior. }\end{array}$ \\
\hline 12. & $\begin{array}{l}\text { Wihardjo dan } \\
\text { Rahmayanti } \\
\text { (2021) }\end{array}$ & $\begin{array}{l}\text { Learning that incorporates the environment becomes more real and } \\
\text { factual as students are exposed to actual environmental events and } \\
\text { conditions. }\end{array}$ \\
\hline \multicolumn{3}{|c|}{ Substance: Education for Sustainable Development (ESD) } \\
\hline 13. & $\begin{array}{l}\text { Kopnina } \\
(2012)\end{array}$ & $\begin{array}{l}\text { It is feared that ESD that employs a diversity approach at the local level } \\
\text { will be unable to achieve environmental education goals. }\end{array}$ \\
\hline 14. & $\begin{array}{l}\text { Indonesian } \\
\text { National } \\
\text { Commission } \\
\text { for UNESCO } \\
(2014)\end{array}$ & $\begin{array}{l}\text { ESD Criteria: } \\
\text { 1. Education is centered on the student, with the teacher serving as a } \\
\text { facilitator Interdisciplinary and holistic education is implemented. } \\
\text { 2. Making use of a variety of pedagogical methods. } \\
\text { 3. Education is based on systems thinking. } \\
\text { 4. Education raises values in order to increase participation and } \\
\text { responsibility in decision making, as well as to improve critical } \\
\text { thinking and problem-solving abilities. } \\
\text { 5. Local cultural approaches, local issues, and global issues are } \\
\text { prioritized in education. } \\
\text { 6. Long-life learning. }\end{array}$ \\
\hline 15. & Shantini (2015) & $\begin{array}{l}\text { - ESD studies not only the environmental pillars as part of development, } \\
\text { but also ecological sustainability, economic sustainability, and society } \\
\text { as actors in development. } \\
\text { - ESD is implemented in formal education through environmental } \\
\text { learning, which focuses on efforts to raise students' awareness and } \\
\text { responsibility, both individually and collectively, by cultivating } \\
\text { environmentally friendly behavior in everyday life in order to create a } \\
\text { clean, healthy, and comfortable environment. }\end{array}$ \\
\hline 16. & $\begin{array}{l}\text { Summers \& } \\
\text { Cutting }(2016)\end{array}$ & $\begin{array}{l}\text { ESD is a strategic tool that is used at all levels of education and at all } \\
\text { ages, with a focus on community diversity. }\end{array}$ \\
\hline 17. & $\begin{array}{l}\text { Simanjuntak } \\
(2017)\end{array}$ & $\begin{array}{l}\text { - The educational path is the foundation for the success of economic } \\
\text { development and industrial development. } \\
\text { Education as a planned investment for future generations to improve the } \\
\text { economy for families and communities }\end{array}$ \\
\hline 18. & $\begin{array}{l}\text { Goldman et al. } \\
(2018)\end{array}$ & $\begin{array}{l}\text { Green School : an effective educational strategy for achieving } \\
\text { sustainable development because it has integrated environmental } \\
\text { sustainability principles into its curriculum and has turned the school } \\
\text { environment into a learning resource. }\end{array}$ \\
\hline 19. & $\begin{array}{l}\text { Tristananda } \\
(2018)\end{array}$ & $\begin{array}{l}\text { - The concept of ESD is derived from environmental education, where } \\
\text { there are behavioral practices to make decisions related to } \\
\text { environmental problems in the region. } \\
\text { - ESD is implemented through curriculum integration, teacher } \\
\text { integration, and integration of ESD concepts into the classroom }\end{array}$ \\
\hline 20. & $\begin{array}{l}\text { Amran et al. } \\
(2020)\end{array}$ & $\begin{array}{l}\text { - The ESD approach can help students develop various characteristics } \\
\text { such as collaboration, communication, environmental management, and } \\
\text { independence. } \\
\text { - Developing critical thinking and creativity can be accomplished by } \\
\text { engaging in outside learning activities on a regular basis. }\end{array}$ \\
\hline
\end{tabular}

The ESD approach is implemented in formal education through environmental learning, which focuses on raising students' awareness and responsibility, both individually and collectively, by cultivating environmentally friendly behavior in everyday life to create a clean, healthy, and comfortable environment. As a result, ESD examines the environmental 
pillars as part of the development and ecological sustainability, economic sustainability, and society as actors in development [15].

The main idea of ESD stems from environmental education because environmental education includes behavioral practices that prepare students to make decisions about environmental issues in their communities. The ESD approach is implemented by integrating the curriculum, integrating teachers, and integrating the ESD concept into the classroom [16]. Teachers in schools that implement environmental education through ESD are more creative because they must compile a curriculum following local conditions and turn schools into learning resources [17].

Schools that use environmental education are a formal education strategy that effectively achieves sustainable development because they have integrated environmental sustainability principles into their curriculum and have made the school environment a learning resource. Environmental education is the key to achieving sustainable development and is a prerequisite for any further efforts before influencing people's actions [18; 19].

Environmental education and ESD are implemented in an interdisciplinary field, beginning at the local level and to the international level, based on community diversity, necessitating additional policies to define local environmental problems integrated into schools' curricula. This is necessary to achieve the goals of implementing environmental education and ESD because each region implementing ESD has different development priorities. In contrast, the threat of environmental sustainability knows no bounds [20].

According to the literature review results, there is a gap from previous research concerning the boundaries of environmental problems at the local level in the implementation of environmental education and ESD. Policy analysis and implementation of the integration of the environmental education curriculum at schools based on regional environmental problems in various subjects based on the level of education are two additional research options that can be conducted for further investigation.

\section{Conclusion}

According to literature reviews and expert opinions, it is critical to research the implementation of environmental education at schools to achieve sustainable development. Both environmental education and ESD play a role in changing people's behavior because they aim to raise students' awareness, knowledge, and skills to produce a generation capable of thinking critically and making decisions to solve environmental problems in their community. The result of this study is expected to be used to develop strategies for implementing environmental education at schools to address environmental issues in the region.

\section{References}

1. A. Daryanto, Suprihatin, Pengantar pendidikan lingkungan hidup, (Gava Media Yogyakarta, 2013)

2. A.S. Keraf, Etika lingkungan hidup, (Buku Kompas Jakarta, 2010)

3. A. M. Hudha, A. Rahardjanto, Etika lingkungan: Teori dan Praktik Pembelajarannya, (UMMPress, 2018)

4. UNESCO, Issues and trends in education for sustainable development, (UNESCO Paris, 2018)

5. L. E. Rahmawati, A. Niasih, H. Kusmanto, H. J. Prayitno, Environmental awareness content for character education in grade 10 in Indonesian language student textbooks, International Journal of Innovation, Creativity and Change, 11, 161-174 (2020) 
6. J. L. Fua, I. S. Wekke, Z. Sabara, R. U. Nurlila, Development of Environmental Care Attitude of Students through Religion Education Approach in Indonesia, IOP Conference Series: Earth and Environmental Science, 175, 1-7 (2018)

7. S. D.Wihardjo, H. Rahmayanti, Pendidikan lingkungan hidup (PT. Nasya Expanding Management Pekalongan, 2021)

8. R. Okasha, M. Mohamed, M. Mansour, Green schools as an interactive learning source, J. Al-Azhar University Engineering Sector, 11, 1091-1100 (2016)

9. D. X. Zhao, B. J. He, F. Q. Meng, The green school project: a means of speeding up sustainable development?, Geoforum, 65, 310-313 (2015)

10. R. Pebriantika, A. Abdurrahman, H. Hariri, Sowiyah, B. Rahman, Leadership in green school practices: a case study of the principal's roles towards reducing global warming risk in Lampung, Indonesia, J. Phys: Conf. Ser., 1572, 1-8 (2020)

11. F. N. Simanjuntak, Pendidikan untuk pembangunan berkelanjutan, J. Dinamika Pendidikan, 10, 169-195 (2017)

12. Komisi Nasional Indonesia untuk UNESCO, Pendidikan untuk pembangunan berkelanjutan (education for sustainable development) di Indonesia: implementasi dan kisah sukses, (Kementerian Pendidikan dan Kebudayaan Jakarta, 2014)

13. D.Summers, R. Cutting, Education for sustainable development in further education: embedding sustainability into teaching, learning and the curriculum, (Palgrave Macmillan London, 2016)

14. A. Amran, I. Jasin, M. Perkasa, M. Satriawan, M. Irwansyah, D. Erwanto, Implementation of education for sustainable development to enhance Indonesian golden generation character, J. Phys: Conf. Ser., 1521, 1-5 (2020)

15. Y. Shantini, Penyelenggaraan EfSD dalam jalur pendidikan di Indonesia, Pedagogia, 13, 136-141 (2015)

16. P. W. Tristananda, Membumikan education for sustainable development (esd) di indonesia dalam menghadapi isu-isu global, Purwadita: J. Agama dan Budaya, 2, 42-49 (2018)

17. A. Iwan, N. Rao, The green school concept: perspectives of stakeholders from awardwinning green preschools in Bali, Berkeley, and Hong Kong, J. Susted., 16 (2017)

18. D. Goldman, O. Ayalon, D. Baum, B. Weiss, Influence of 'green school certification' on students' environmental literacy and adoption of sustainable practice by schools. J. Clean Prod., 183, 1300-1313 (2018)

19. R. Tucker, P. Izadpanahi, Live green, think green: Sustainable school architecture and children's environmental attitudes and behaviors, J. Jenvp, 51, 209-216. (2017)

20. H. Kopnina, Education for sustainable development (ESD): the turn away from 'environment'in environmental education?, Environmental Education Research, 18, 699717 (2012) 